\title{
GETTING OUT OF THE QUICKSAND (1): REVISION OF THE PLANT RECORDING SYSTEM IN THE BOTANICAL GARDEN OF THE FACULTY OF SCIENCE, UNIVERSITY OF ZAGREB
}

\author{
Alan Budisavljević \& Sanja Kovačić* \\ Botanical Garden, Department of Biology, Faculty of Science, University of Zagreb, \\ Marulićev trg 9a, HR-10000 Zagreb, Croatia (*e-mail: sanja.kovacic@biol.pmf.hr)
}

Budisavljević, A. \& Kovačić, S.: Getting out of the Quicksand (1): Revision of Plant Recording System in the Botanical Garden of the Faculty of Science, University of Zagreb. Nat. Croat., Vol. 29, No. 1, 173-184, 2020, Zagreb.

The current plant recording system of the Botanical Garden of the Faculty of Science is a system stuck in time with a faded historical background. Intensive archival research was conducted to reconstruct and review the entire history of the plant recording system in the Garden and the data available in it. This way the organizational history is preserved for future generations and the knowledge and data collected for this article, will facilitate the Garden's plant recording system moving into the $21^{\text {st }}$ century.

Key words: archive, database, organizational study, historic plant collections

Budisavljević, A. \& Kovačić, S.: Izlazak iz živog pijeska (1): Revizija sustava bilježenja biljnih vrsta u Botaničkom vrtu Prirodoslovno-matematičkog fakulteta Sveučilišta u Zagrebu. Nat. Croat., Vol. 29, No. 1, 173-184, 2020, Zagreb.

Povijest sustava za bilježenje zbirki biljaka u Botaničkom vrtu Prirodoslovno-matematičkog fakulteta i postupci u upravljanju njime većinom su nepoznati i nezabilježeni. Provedeno je arhivističko istraživanje radi povijesne rekonstrukcije upravljanja sustavom za bilježenje biljaka i uvida u kvantitativnu i kvalitativnu količinu povijesnih podataka o našim zbirkama. Ovim radom čuvamo dio povijesti upravljanja Vrtom za buduće generacije, dok će rezultati prikupljeni istraživanjem usmjeriti daljnji razvoj sustava za bilježenje biljaka u našem Botaničkom vrtu.

Ključne riječi: arhiva, baze podataka, institucijsko istraživanje, povijesne zbirke biljaka

\section{INTRODUCTION}

The Botanical Garden of the Faculty of Science, University of Zagreb (below "the Botanical Garden" or "the Garden"), established in 1889, is the oldest botanical garden in Croatia (Kovačić \& Stamenković, 2014). Throughout its history, which spans over 130 years the Garden's influence branched out to different levels of education in university studies, scientific research in plant sciences and ex-situ conservation. The plant collections of native and foreign flora are essentially the backbone of the Garden's main functions and as such, expanding and documenting them is in fact the primary objective for the Garden's field of work.

To properly manage, organize and expand their collections, fundamental to the work of botanical gardens is the use of a methodical system for recording the plants. 
Managing and organizing the plant collections in the past had to face various challenges in our Garden. Not long after its establishment, the Garden was confronted with adverse historical circumstances. The oppressive aftermath of the First and the Second World War took a toll of the collections and the documenting activities they entailed. Regula-Bevilacqua (1997) mentions several occasions on which there was a significant insufficiency of financial support even for the basic operations. Furthermore, the plant collections took a direct blow as they were devastated during an air raid on Zagreb in 1944. Therefore, one should not be surprised that at present there are not many preserved archival records on the Garden's collections from the first half of the $20^{\text {th }}$ century. The data about the living collections in the Garden at that time was documented in only a few manuscripts or handwritten accession books and they represent the first plant recording system in the Garden.

At the beginning of the second half of the $20^{\text {th }}$ century, documenting the collection took an organized and systematic approach with the introduction of a card system by the first manager of the Garden - Dr. Sala Ungar (Regula-BevilaceuA, 1997). The card database system was a part of the solution to modernize the Garden after the wartime and allow it to recover from its dilapidated state. The system represents the first physical, non-electronic, methodical database for mapping and documenting the plant collection and it is still actively used in the Garden. One card represents one plant species present in the Garden with all of the relevant information e. g. origin of the sample, the area in which it is planted, date of the acquisition etc. At present, it contains information about 70 years of plant cultivation in the Garden, covering over 28,000 cards (KoVAČıć, 2015).

The further evolution of the plant recording system, which was already lagging behind, unfortunately stumbled on the same stone as the transition from accession books to the physical database - the Garden was yet again caught up in a war. The Croatian War of Independence during the 1990s postponed the transition of the plant recording system from analogue to digital. To illustrate the severity of the problem, most of the other botanical gardens had already developed some sort of computerized database before the $90 \mathrm{~s}$ - one of the first applications of computers in botany was reported in 1962 (DALCIN, 2014) and databases for plant recording systems appeared in practical application in the 70s (Wyatт \& Sucher, 2014). Our Garden finally seized the opportunity to evolve its plant recording system, practically in the nick of time, when the migration was made possible by the development of the national botanical database Flora Croatica Database (FCD, 2020) in 2004. However, the Garden's struggles to move on were once again dogged by misfortune. During the digitalization of data, it was recognized that the card system had some faults that happened during the long and intensive usage of it, while limited financial and human resources interrupted the attempt to solve those problems. Consequently, it was decided that only plants alive and present at the time of the transition would enter the digital database, to avoid filling the new database with faulty information. The quantity, origin and severity of these flaws in the card database were never thoroughly analyzed and that was the final nail in the coffin that interrupted the full transition into the digital plant recording system. On account of that, the usage of the card system continued, despite the existence of the digital database since it was the only plant recording system that was fully integrated into the business process of the Garden and contained the full history of the plant collections. Thus, temporary solutions focused on avoiding problems rather than 
solving them were applied. This added an additional layer of complexity, making the old system arduous to use. Moreover, every time new data were added, the quicksand effect intensified.

After the tedious and perplexed history of the plant recording system in the Garden, it is high time to resolve the problem of the plant recording system and to transition completely to a digital system. This article is the first in a planned series that will document this endeavor through multiple stages implementing a multidisciplinary approach of archival research, historical organization study, botany and information technology (IT). In the first phase elaborated in this article, four main steps received assiduous attention and research: (i) historical reconstruction of the plant recording system from the establishment of the Garden till 2020, (ii) analysis and assessment of the plant data that can be salvaged from preserved archival records up until the second half of the $20^{\text {th }}$ century, (iii) comprehensive analysis of data management in and organizational practices concerning the use of the physical card database system through time and (iv) assessment of the origin of the flaws in the card system that arose from its excessive use.

Finally, the overall purpose of this article is not only to provide a practical perspective related to important botanical data or the future development of the plant recording system but also to conserve the Garden's history for future generations.

\section{MATERIALS \& METHODS}

Eight official records were used for the revision of the plant recording system of the Botanical Garden (Fig. 1): (i) manuscripts published shortly after the Garden's establishment, (ii) accession books written in the first part of the $20^{\text {th }}$ century, (iii) chronicles of the head gardeners, (iv) preserved issues of Delectus seminum, (v) card database system, (vi) three inventory notebooks from the $60 \mathrm{~s}$, (vii) plant propagation books and (viii) the online database Flora Croatica Database (FCD, 2020). Additionally, as supplementary material we used unofficial, internal digital or handwritten checklists of the employees. Besides the written records, the research also consisted of collecting as much information as possible about the plant recording system from the current and former employees in the Garden.

The archival research was conducted with the historiographic approach defined by Mohr \& Ventresca (2002). Both descending and ascending models of analysis of the data were used. However, during the research most of the times emphasis was put on the ascending model. In other words, causality was defined more often through the analysis of smaller practices or the logic of actions in the management of the plant recording system.

The results of the archival study have been represented chronologically as reconstructed organizational practices concerning the plant recording system in the Garden. The source with the most abundant data about the plant collection - the card system database has been researched with a higher degree of attention since it had the most ambiguous and non-defined management procedures throughout the history of the Garden. To keep the text readable and coherent, numerous clues from the archival research that were the building blocks for the reconstruction of the card database management were left out on purpose. Furthermore, a rough estimate on the amount of the data about the plant collection that would be salvageable before the 1950s has also been 


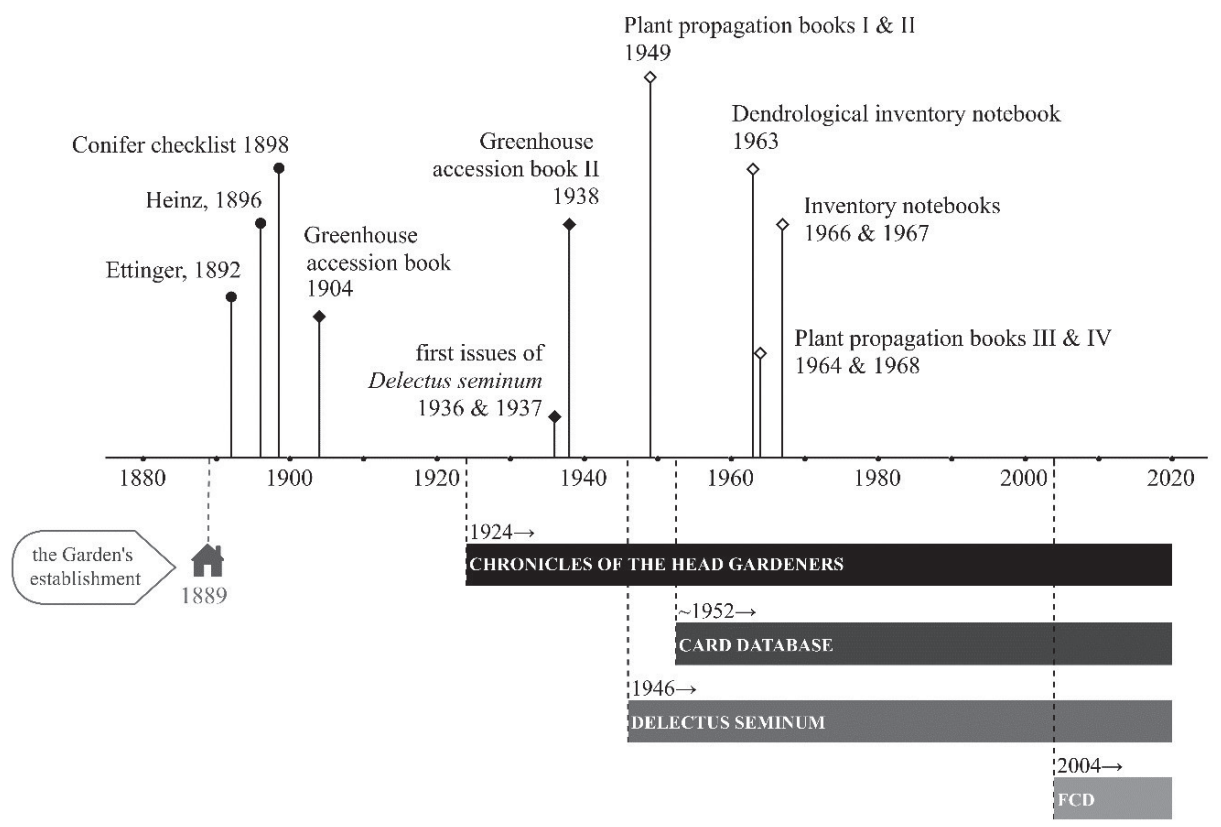

Fig. 1. All of the archival records used for the revision of the plant recording system of the Botanical Garden of the Faculty of Science, University of Zagreb, depending on their time of creation. The continuous sources of data with multiple records are situated under the timeline in boxes, while discrete sources of data are located above. Endings of the lines that mark the discrete records are labeled with different shapes depending on the part of the century they are representing: $(\bullet)$ end of the $19^{\text {th }}$ century, $(\diamond)$ first half of the $20^{\text {th }}$ century and $(\diamond)$ second half of the $20^{\text {th }}$ century. Abbrevation "FCD" stands for Flora Croatica Database.

made. Representation of the results has been approached with a line (area) graph and a histogram. The origin and the reasoning for different flaws and mistakes in the plant recording system's design have been elaborated throughout the chronological overview with the additional, separated elaboration about the card database problems.

The support of various computer programs was used to produce the results. All diagrams were created using draw.io (https://www.draw.io/). The graphs were created using R version 3.6.3 (R Development Core Team, 2013) and Microsoft Excel 2019 was used for data processing. Certain illegible materials have been scanned and processed by the photo processing software Adobe Photoshop to increase readability and extract the information required.

\section{RESULTS \&DISCUSSION}

\section{The plant recording system from 1889 to 1950 and its data abundancy}

In the plant recording system before the introduction of the card database in the 1950s, the data about the living collection in the Garden was documented in manuscripts or handwritten accession books. At first, the emphasis was put on publishing the data about the collection in the form of a manuscript and two of these records date 
back to 1892 and 1896 (EtTInger, 1892; Heinz, 1896). These manuscripts listed a considerable amount of species that were originally a part of the Garden's rich collection (Fig. 2, a). It is important to note that the record from the founder of the Garden, Professor Antun Heinz, in 1896 reports even more data, but the data could not be quantified since it was defined in ambiguous plurality. For instance, numerous genera were defined with constructions such as "and many more representatives of". Possible reasons for this could have been the format of the manuscript that needed to be concise or, as Heinz noted in several genera across his manuscript, a lot of the cultivated plant materials were juvenile and it was hard to determine or confirm the exact species at that time. The manuscript from the 1896 provides the biggest data accumulation across all of the collections in the Garden for the $19^{\text {th }}$ century, whereas the manuscript from 1892 provides the richest insight into one specific collection-the collection consisting of shrubs and trees (997 entries on different species and cultivars).

ETTINGER (1892) also wrote that the Garden was still quite unheard-of, not just in the neighboring countries but in its home country as well. For that reason, publicly available manuscripts were a proficient way to spread the word about the Garden's quality and assure communal affirmation and recognition. At the end of the $19^{\text {th }}$ century, the initial manuscripts were largely replaced by the internal ink-handwritten checklists and accession books, such as the handwritten accession book of coniferous species from 1898 that expanded the data about the Garden's original collection.

At the beginning of the $20^{\text {th }}$ century, the finest example of an accession book-the Greenhouse book used for inventorying years 1904 and 1905 presents a systematic and profound approach to plant recording in the Garden. Each glasshouse plant sample was listed in the book with its full Latin name and respective higher taxonomic categories. Moreover, for each plant sample there was an estimation of its monetary value and the full collection was priced at the end of a certain period. For example, in the year 1904 the person in charge estimated the whole value of the glasshouse collection at 4,470 Kronen and 51 fillér.

Contrary to the initial abundance of the data preserved in the Greenhouse accession book from 1904, the sources of information about the state of its plant collections from the first half of the $20^{\text {th }}$ century are certainly scarce. This is an apparent consequence of the historical events that are well elaborated in the introductory part of this article and accordingly it is consistent with the organizational history provided by REGULA-BevILACQUA (1997). There is only one additional handwritten accession book that partially covers the collection of the glasshouse plants for the year of 1938 and one notebook that lists a small number of plants sold from 1932 till 1937. Furthermore, supplementary materials for the 1930s can only be found in the two issues of Delectus seminum that were preserved for the years 1936 and 1937. These lists of seeds and spores collected from the plants growing in the Garden are an implicit and only partial source of the information about the content of the plant collection during the years they cover. Considering the small amount of written data, it is hard to pinpoint exactly what happened to the diverse, rich and numerous plant collection from the establishment of the Garden. The absent records massively affect the line graph representing the preserved plant data (Fig. 2, a) and this is even more apparent in the distribution of data across the several decades (Fig. 2, b). The only positive trend from that period is the gradual rise of data found in the preserved consecutive issues of the Delectus seminum (Fig. 2, a, 1936, 1937, 1946-1948). This indicates the slow but persistent efforts of the Garden's 
staff and curators to maintain and develop the Garden despite the hard times. The spike of plant data availability after the 1930s follows the arrival of the first manager of the Garden. The comprehensive archival research of the head gardener's chronicles for the year 1948 revealed that Sala Ungar was appointed to her duties in the Garden on $19^{\text {th }}$ August 1948. Before the introduction of the card system, Ungar reconstructed the business model of the Garden and introduced a new type of accession book - the plant propagation book. Plant propagation books I and II are preserved in our archive and they cover the years from 1949-1950 and 1950-1952, respectively. By virtue of this new type of record and issues of Delectus seminum, which became an annual publication, a lot of data was preserved around the 1950s, essentially leading the plant recording system out of its first crisis.
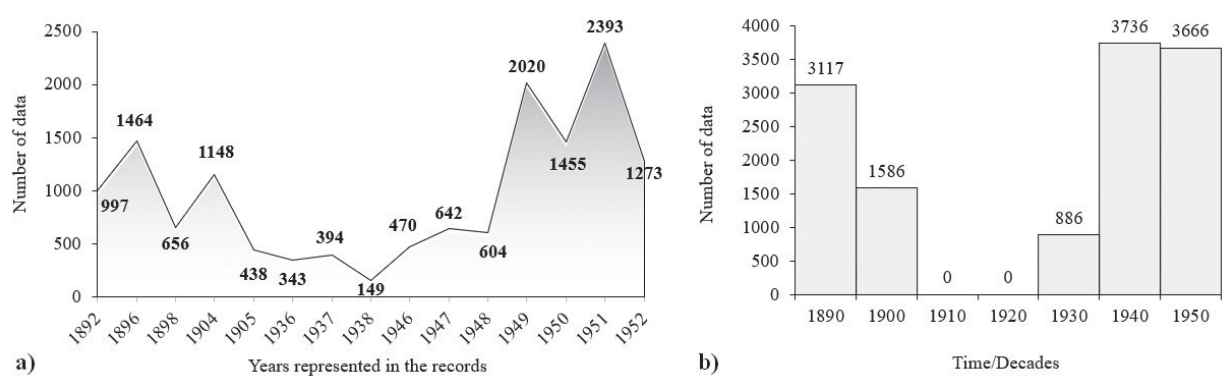

Fig. 2. Preserved plant record data in archival records of the Botanical Garden of the Faculty of Science, University of Zagreb from the 1889 till 1952 presented as:

(a) the area graph where the quantity of recorded plant data is shown depending on the date of origin written in the archival record and (b) the histogram with the distribution of recorded plant data across time.

\section{Establishment of the card database and its priciples for data input from 1953 till 1960}

The flourishing of plant data quantity from the end of the 1940s continued well into the 1950s primarily due to the new card database system. Based on the archival research the probable date of the system's initiation was around the year 1953. This is the more accurate information then that previously supplied in Kovačić (2015) which was handed down from one generation to another, i.e. 1948. Considering the fact that Dr. Sala Ungar was appointed as the first manager of the Garden in August 1948, it is highly unlikely that she managed to start the new system in just four months. Numerous clues put the actual dating of the card database even further into the 50s. Firstly, there is no mention of the new system in the head gardener's chronicles from 1948 till 1950 that were inspected. Secondly, from the inspection of the Plant propagation books I and II, not even one plant sample that germinated from the 1949 till 1952 was found in the card system. This was the strongest evidence to refute the idea of the card system's establishment in 1948, since the latter Plant propagation books numbered III and IV had a strict and regular transition of the data to the card system. Thirdly, from the overall inspection of the card system, there is a noticeable trend of greater card data input from the 1953 with samples that have a known origin and date of entry to the collection. Accordingly, the establishment of the card system can only be dated between $2^{\text {nd }}$ February 1952, which was the last entry in Plant propagation book II, and somewhere in 1953. 
Regula-Bevilacqua (1997) states that one of the first things Ungar did as a manager was to make a systematic listing of plants presently alive in the Garden and mentions that the exact number of species was 1,021. The origin of this initial number of the species in the Garden right before 1950s was probably handed down orally, since the checklist in question is not preserved in the Garden's archive. It will be one of the goals for the future research endeavors to reconstruct this list after the complete digitalization of the card system. From the archival research on the card system it was apparent that the plant samples without the associated attribute of origin were predominantly input into the card system from 1953 till 1960, with decreasing occurrence until 1965.

The principle for initial data input of the card system was at first conceptually easy to grasp and apply. Each species was assigned to a separate card and all samples of the same species whose origin was different were grouped on the same card. Samples were organized as a list where they were numbered with alphabetical letters and ordered vertically one sample after another. Therefore, if a species had been supplied to the collection on several occasions throughout the years, the data would have been grouped and stored on one physical piece of paper.

The whole card database was alphabetically ordered by the Latin name of the species and this was the only possible way to provide efficient searchability.

\section{The beginning of the systematic updates of the data stored in the card data- base and introduction of the indexing system that changed its operational framework in the $60 \mathrm{~s}$}

From the year 1960, systematic re-cataloging of the plant collections began in the Garden. The earliest inventory update noted in the card database was 1961, and 1962 was the year in which the most plants were checked and validated. Most of the cards were checked at least once during the 60s. The fact that five inventory notebooks were preserved from the 60 s indicates the great emphasis that was put onto the evaluation of the data relevancy.

Ungar organized many field trips in the 60s with the purpose of enriching the Garden's collection of native flora, and Regula-Bevilacqua, the curator at the time, later to become the second manager of the Garden, focused with considerable dedication on these collections. From 1962, she kept a notebook in which all of the determined native flora brought from the field was listed. In the 1969 after a considerable amount of undetermined plant material was brought to the Garden from the Pelješac peninsula, an additional notebook was used to list and provisionally mark these "nameless" plant samples until their complete determination. This act of numbering the plant species was "the trend" that was then noticed in the Delectus seminum publications of other botanical gardens. This observation led the staff to introduce an inconvenient indexing method on top of the existing card database in the year of 1969 with the idea that all living and present plant species in the garden should get a unique number. The notebook from 1962 with the list of the native flora was repurposed as an indexing list for the native speciesits original title was crossed out and the new title was written: "List of the native species in the flora of Yugoslavia". Furthermore, third notebook was opened to be used in the indexing method for foreign species in the Garden. Each notebook had a different range of numbers available for species input and this was marked on the first page of the notebook. In the following years, as soon as a notebook was filled, a new notebook was opened and its number of rows dictated the next occupied range of indexing numbers. Confusingly enough, some notebooks carry titles that were relevant for something com- 
pletely different, but as they were reused as an indexing notebook, no adequate change of the title was made. Eventually this unhandy application of the database's key (referred to in the Garden as the indexing numbers) led to a confusing disarray of the key through multiple notebooks (Tab. 1).

Even though the introduced numbers were comprehended as a key/index, the numbers actually did not fill the role that they should have-the searchability of the card system was not enhanced because the database was never ordered by ascending index numbers. It did not take the form of a reference key either, as physical plant materials in the collections were not tagged with these keys at the time. These index notebooks had a different value that was comprehended at the time as a sort of practicality - the notebooks were a collection of extracted data of the living plants present in the Garden. They appeared as two different database queries - one querying for the presently living native species and the other for the foreign species. However, these lists could not have been data relevant in that perspective for a long time, an additional reason for further changes in the card database management.

Tab. 1. Notebooks used in the indexing system of the card database from 1969 till 2020 in the Botanical Garden of the Faculty of Science, University of Zagreb.

\begin{tabular}{|c|c|c|c|c|c|}
\hline & Title of the indexing notebook & Part & Origin & $\begin{array}{l}\text { Indexing } \\
\text { range }\end{array}$ & $\begin{array}{l}\text { Estimated } \\
\text { starting date }\end{array}$ \\
\hline 1. & $\begin{array}{l}\text { List of the native species in flora of Yugoslavia } \\
\text { (Croatian: „Popis autohtonih vrsta u flori Jugoslavije“) }\end{array}$ & I & $\mathrm{N}$ & $1-1999$ & 1969 \\
\hline 2. & $\begin{array}{l}\text { List of determined plants brought from the field in } 1969 \\
\text { (Croatian:“Popis određenog bilja donešenog sa terena } \\
\text { god. 1969") }\end{array}$ & II & $\mathrm{N}$ & 8001-10999 & 2001 \\
\hline 3. & Untitled & $\mathrm{I}$ & $\mathrm{F}$ & $2000-5800$ & 1969 \\
\hline 4. & $\begin{array}{l}\text { Foreign species } \\
\text { (Croatian: „Strane vrste“) }\end{array}$ & II & $\mathrm{F}$ & $\begin{array}{c}5801-8000 ; \\
11000-12450\end{array}$ & 1975 \\
\hline 5. & $\begin{array}{l}\text { Foreign species } \\
\text { (Croatian: „Strane vrste“) }\end{array}$ & III & F & $12451-14999$ & 2009 \\
\hline 6. & $\begin{array}{l}\text { Annual species } \\
\text { (Croatian: „Jednoljetnice“) }\end{array}$ & - & $\mathrm{N} / \mathrm{F}$ & $15000-\ldots$ & 2004 \\
\hline 7. & $\begin{array}{l}\text { List of undetermined species } \\
\text { (Croatian: „Popis neodredenih vrsta-po rednim } \\
\text { brojevima“) }\end{array}$ & - & $\mathrm{N}$ & $9001-10855$ & 1962 \\
\hline
\end{tabular}

\section{The first compartmentalization of the card database and the loss of data}

The plant collection's size grew steadily from the limited plant species located in the garden at the turn of the 1950s. UnGAR $(1963 ; 1971)$ stated that the collection had 5,000 species in 1963 and 6,500 in 1971. Regula-Bevilaqua (1988) further confirmed a steep rise of new plant species in the Garden as their number increased to about 10,000 in 1978. The almost perfect fit of this data $\left(R^{2}=0.9615\right.$, data not shown) to the linear regression proves the incredible dedication of the Garden's staff to upgrading the Garden's collections throughout the years with the maximum efficiency inside the frames of the constantly low financial and human resources. At the beginning of the 1980 s the card database system had somewhere between 15,000 and 20,000 cards stored in it and became inconvenient to work with on a daily basis, primarily because it became filled with data and the retrieval of the information wanted became a time-con- 
suming act. Furthermore, the systematic inventory updates across the two decades revealed a lot of species that had died off and as such did not belong to the Garden's collection anymore. This made the card system even more inconvenient, since it added an additional group of data scattered between the cards with living plants.

To remedy these problems, the decision was made to divide the whole card database into two compartments - one contained cards from then present and living species and the other was continuously filled with redundant cards as the plant species died off in the Garden. These two compartments are referred as the 'active' and 'passive' parts of the card database by Kovačić (2015). From 1981 a major undertaking started with the intention of updating all of the Garden's business aspects and most of its infrastructure before its $100^{\text {th }}$ anniversary. The second manager of the Garden, Dr. Ljerka Regula-Bevilacqua led all of the upgrades and revisions. In 1985, the first revision of the card system was made with the emphasis put on synonymy, data accuracy and expanding the information each card can contain with the introduction of additional attributes. At the same time, the card database was connected through the index numbers in the notebooks to the actual plants in the Garden, as they were labeled with numbers beside their respective Latin names.

In 1986, after several costly repairs such as the temperate Glasshouse reconstruction, the main Garden fence and the public toilet, the Garden's available sources of financial sponsorship dried out, leaving it in an impecunious state. There were still several structural adaptations left to be done before the big anniversary and the sudden deficit of pricy custom-made blank paper cards forced the Garden's staff to improvise and enforce new rules to continue to work on the expansion of the collections.

In 1986 a new notebook was introduced into the plant recording system - titled "Available numbers" (Croatian: "Slobodni brojevi"), it contained randomly copied index numbers from the compartment of the card database with plants that died off. Once new species arrived in the Garden and needed to become a part of the collection, their data were written over a randomly picked card from the passive, "died off" compartment. Secondly, it was indexed with the first available non-crossed number in the new notebook. Thirdly, the allocated index number was searched for in its respective index notebook, the former species next to the allocated number was erased and the new species was assigned to that index number. Additionally, if a random plant in the Garden died off, the curators placed the card into its designated compartment and wrote the "discarded" species' number into the notebook with the available numbers. This procedure seemingly killed two birds with one stone-it solved a practical problem of blank card deficiency and introduced the method by which index notebooks would continue to have their original conception as the indefinite, self-updated query about the presently alive plants in the Garden. However, it also made a significant leakage of historical data from the database.

With the analysis of the notebook with the available numbers, 1616 of them were written into it and crossed out, which means that this is a minimal count of the lost data that can be reconstructed only if the data card with that index number was not reused or if the name of the discarded species in the index notebook was crossed out in such a way as to leave it readable. Unfortunately, a ruminative lament about the importance of the historical data preservation came a day late and a dollar short because the practice was terminated just around the year 2017. In other words, we are 
not sure how devastating this period was for the loss of data and a comprehensive reconstruction will be needed in the future to assess this manner.

\section{The transition of the data into the digital database and further compartmen- talization of the card database in the $21^{\text {st }}$ century}

During the war in the 1990s, the collections' content declined from its peak in the 1980s and another revision of the card database was needed. To revitalize the collections, new cabinets were made for storage and each card in the active compartment was reviewed from 2000 till 2004. The transition onto the digital database was set in motion in 2004.

The full transition to the digital database was problematic as the outcomes of the card database's own limitations became more apparent. The card database was full of duplicates because synonymy or the presence of the species was not checked properly in the existing data before a new input. Furthermore, some cards were misplaced as indicated by the index numbers, specified only with the genus or faulty data inputs, e.g. some species had a typo in their name which is hardly traceable since databases for certain obscure past cultivars do not exist. The biggest problem at the time was that many cards with active status, i.e. living plants that still belonged to the collection, were misplaced into the passive part of the database. Extracting the data through tedious revision of more than 20000 cards in the passive compartment was out of the question as no technical capacities were available, so most of the time another duplicate was made with a shortage of relevant information.

The digitalization was performed only on the active part of the card system, with emphasis put onto those samples that were still alive. In other words, no historical data about the plant cultivation was entered into the new database, even from the active compartment. Surprisingly enough, the loss of the historical data did not come into the spotlight, even though some of the cards with an active status were dispersed through the passive compartment, which also jeopardized the data about the present plants.

Around 2005, a further division of the card database occurred. Three new compartments were created: (i) one for the newly arrived species that awaited their introduction to the digital database, (ii) one for the species that had an unknown status i.e. living or dead, and (iii) one for the annual plants that got their own indexing notebook and dedicated curator in 2004 (Tab. 1).

The introduction of the digital database did not do much for the plant recording system and consequently, the use of the card database was set in stone for the future management of the plant recording system.

\section{Overview of the Garden's card database system problems and their origin}

The complicated situation with the card database arose for a multitude of reasons. Firstly, the card database was used for far too long and by too many people. Three generations of curators were working with it throughout 70 years and its usage still continues up to this date. The background for this was the slow rate of progression of the plant recording system to a digital form, for the numerous historical reasons already discussed in this article. Secondly, the card system's operational framework was changed multiple times in its history and this provided the room for mistakes. Thirdly, there was never a complete guide or a rulebook that would ensure the uniformity of the data input. All of these arguments were hardly solvable since the underlining issue of each argument was 
the card database itself. This type of database system is primitive and it cannot keep up the data integrity since the medium used is a physical piece of paper subjected to the ever-changing winds of numerous variables. Human errors, material deterioration, material displacement, unreliable and inconsistent input rules are just a few of the limiting factors of that medium. The modern databases have different underlying systems and logics that ensure data integrity - something the physical database lacks. The most basic principle in the digital database is the database identification key-a specific, unique number appointed to each data input. An embodiment of the similar principle was introduced in the card system in the form of indexing numbers. However, these numbers were conceptualized and applied in a way that was far away from the idea and function of the identification key: (i) the index key was awkwardly segmented, (ii) all of the plants input in the database were not marked with a key since it was introduced almost 20 years after the conception of the card database, (iii) a lot of the cards in the passive and active compartments shared the same key. The nature of the index numbering is the most deceiving part of the card system - it appears to be a primary key, but at the same time it does not fill the basic requirements to be one at all.

If the Garden were not entwined with a series of unfortunate historical events, the card database system would have migrated to a digital one a lot sooner than it actually did, which would have prevented a lot of complications.

In the beginning of the 2020, after the research conducted and during the writing of this article, all of the compartments were combined and all the cards were again ordered alphabetically. The errors and duplicated cards can now be spotted more easily, searchability is tremendously enhanced, while the reconstruction and the digitalization of the lost or jeopardized data can be conducted in a more approachable way.

\section{CONCLUSION}

To eliminate the shortcomings of the plant recording system that are impacting the management of the collections and to ensure that the future system is reliable, it is essential to: (i) adjust the digital database to the holistic, contemporary approach in plant curatorship and update the data already in it, (ii) digitalize the data from the card database and the archive records to prevent data loss, (iii) conduct a botanical revision of the cards that are riddled with problems, (iv) reconstruct the erased plant data with backtracking, (v) update the Garden's business model in accordance to the new plant recording system, (vi) ensure an accessible and uniform data input approach and offer an adequate educational support and guide materials for the Garden's staff and (vii) optimize the system for the successful implementation of the Garden's strategic plans in the future and a broader field of work.

The present state of the card system - its indexing system, additional rules of index repurposing and its five different compartments was an outdated mess that needed considerable amount of contemplation before the complexity of its state could be grasped. The current and former employees in the Garden knew partial and mostly practical applications of the system, but the entire reconstruction, historical background, management procedures and decisions that shaped the plant recording system as a whole were unknown or forgotten. The information about it was partially handed down from one generation to another with strong informational redundancy or hidden clues scattered through 28,000 cards and countless ink-written pages from the dusty records of the 
Garden's archive. As this article comes to an end, a new perspective opens for the Garden's plant recording system in the future so that its well-deserved evolution into the $21^{\text {st }}$ century can finally take place. History defines our present and impacts our ability to progress, so let this article be a reminder on how to avoid sinking into a quicksand of oblivion-document the history of your institutions.

\section{ACKNOWLEDGEMENTS}

We would like to express our sincere gratitude to Dr. Ljerka Regula-Bevilacqua, retired manager of the Botanical Garden, for sharing stories and unpublished data on the history of our archives.

In late 2019, the project documentation linked to this article was the subject of a grant application to the Croatian Ministry of Culture, which provided the Botanical Garden with financial support for the digitalisation of our archives, for which we are grateful.

Received March 13, 2020

\section{REFERENCES}

DAlcin, E., 2014: Cultivating bits and bytes. Journal of Botanic Gardens Conservation International 11(2), 23-25.

EtTInger, J., 1892: Botanički vrt kr. sveučilišta Franje Josipa I. u Zagrebu. [Botanical garden of the royal University of the Franjo Josip I. in Zagreb]. Sumarski list 9-10, 409-422.

FCD, 2020: Flora Croatica Database. Available from: https://hirc.botanic.hr/fcd/ [accessed February 2020].

Heinz, A., 1896: Kr. Botanički vrt u Zagrebu. [Royal Botanical Garden in Zagreb] Croatian. Glasnik hrv. naravosl. društva 1-6, 1-54.

Kovačić, S., 2015: Plethora of Plants - Collections of the Botanical Garden, Faculty of Science, University of Zagreb (1): Temperate Glasshouse Exotics - historic overview. Natura Croatica 24(2), 361-397.

Kovačić, S. \& StamenKović, V. (eds.), 2014: Fifty Sights at the Botanical garden: for passers-by, strollers and real enthusiasts - a guide to the Botanical Garden, Faculty of Science, University of Zagreb. Zagreb (HR): self-publishing. Available from: https://www. researchgate.net/publication/286933393

Mohr, J. W. \& Ventresca, M., 2002: Archival Research Methods, Blackwell Publishers LTd., DOI: 10.1002/9781405164061.ch35.

R Core TeAm, 2013: R: A language and environment for statistical computing. Vienna: R Foundation for Statistical Computing.

Regula-Bevilacqua, Lj., 1997: Botanički vrt Prirodoslovno-matematičkog fakulteta Sveučilišta u Zagrebu. [Botanical garden of the Faculty of Science, University of Zagreb] Croatian. Zagreb (HR): Školska knjiga.

Regula-Bevilacqua, Lj., 1988: In memoriam dr. Sala Ungar (15.9.1908-21.10.1988). [In memoriam Sala Ungar (15 $5^{\text {th }}$ September 1908-21 $1^{\text {st }}$ October 1988)] Croatian. Priroda 3-4, 42.

UnGAR, S., 1963: Vodič kroz Botanički vrt Prirodoslovno-matematičkog fakulteta u Zagrebu. [A guide to the Botanical garden of the Faculty of Science, University of Zagreb] Croatian. First edition. Zagreb (HR): self-publishing.

UnGAR, S., 1971: Vodič kroz Botanički vrt Prirodoslovno-matematičkog fakulteta u Zagrebu. [A guide to the Botanical garden of the Faculty of Science, University of Zagreb] Croatian. Second edition. Zagreb (HR): self-publishing.

Wyatt, A. \& Sucher, R., 2014: The evolution of living collections management to support plant conservation. Journal of Botanic Gardens Conservation International 11(2), 7-10. 